\section{Comment on serotypes and susceptibility of Streptococcus pneumoniae strains isolated from children in Mexico}

Dear Editor: Villaseñor-Sierra and colleagues present data on the serotypes and antibiotic susceptibility of $S$. pneumoniae strains from 48 children 1 to 12 years of age with invasive infections and 50 carriers in Mexico from March 2000 to May 2005. ${ }^{1}$ Serotype distribution, in addition to incidence of disease, is an important parameter to assess conjugate vaccination and this information adds to the published data on pneumococcal serotype distribution in Mexico. ${ }^{2-16}$

Coverage of the currently licensed heptavalent conjugate vaccine (containing serotypes 4, 6B, 9V, 14, 18C, 19F and $23 \mathrm{~F}$ conjugated to the carrier protein $\mathrm{CRM}_{197}$ ) and the investigational 10-valent vaccine (containing serotypes $1,4,5,6 \mathrm{~B}$, $7 \mathrm{~F}, 9 \mathrm{~V}, 14,18 \mathrm{C}, 19 \mathrm{~F}$ and $23 \mathrm{~F}$ conjugated to protein $\mathrm{D}$, diphtheria and tetanus carrier proteins) for meningeal, non-meningeal invasive infections and nasopharyngeal carriage are shown in table I of the article by Villaseñor-Sierra and colleagues. ${ }^{1}$

We would like to point out that there is currently another investigational vaccine, containing 13 serotypes $(1,3,4,5$, $6 \mathrm{~A}, 6 \mathrm{~B}, 7 \mathrm{~F}, 9 \mathrm{~V}, 14,18 \mathrm{C}, 19 \mathrm{~A}, 19 \mathrm{~F}$ and $23 \mathrm{~F}$ conjugated to the carrier protein $\mathrm{CRM}_{197}$ ) that would further expand coverage of pneumococcal serotypes causing disease in Mexico. ${ }^{17-18}$ Although it is not possible to calculate the exact coverage offered by the investigational 13-valent vaccine with the data presented, it would cover at least $78 \%$ of the meningeal isolates recovered in this study, compared to 58\% and 65\% of the heptavalent conjugate vaccine and investigational 10-valent vaccine, respectively. This expanded coverage of the investigational 13-valent vaccine is mainly due to inclusion of serotype 3 , which is the second most common serotype isolated from patients with meningitis representing $13 \%$ of these isolates. ${ }^{1}$ Serotypes 6A and 19A, in addition to the most likely antibiotic- resistant serotypes $(6 \mathrm{~B}, 14,19 \mathrm{~F}$ and $23 \mathrm{~F}$ ) found in the heptavalent conjugate pneumococcal vaccine, are included in the investigational 13-valent vaccine, thus potentially offering expanded coverage for antibiotic-resistant disease shown to be prevalent in Mexico.

The WHO has recommended the incorporation of the currently licensed heptavalent pneumococal conjugate vaccine into national immunization programs as a priority, globally. ${ }^{19}$ Many countries, including Mexico, have taken this action. The data from Villaseñor-Sierra and coworkers will help guide the incorporation of new generations of conjugate vaccines, with expanded serotype coverage into these programs.

\section{Gail L. Rodgers, MD. (I) rodgerg@wyetk.com Gerardo Mercado, MD, (I) Hans Bierschwale, MD, (I) Peter Paradiso, PhD. (I) \\ (I) Wyeth Mexico and Wyeth Pharmaceuticals, Collegeville, Pennsylvania, USA}

\section{References}

I.Villaseñor-Sierra A, Lomas-Bautista M,AguilarBenavides S, Martínez-Aguilar G. Serotypes and susceptibility of Streptococcus pneumoniae strains isolated from children in Mexico. Salud Publica Mex 2008;50:330-333.

2. Calderón-Jaimes E, Echániz-Avilés G, CondeGonzález C, Rivera-Sánchez R, Barriga-Angulo $\mathrm{G}$, Solórzano-Santos F, et al. Resistancia y serotipificación de Streptococcus pneumoniae aisladas de niños portadores asintomáticos y enfermos. Bol Med Hosp Infant Mex 1993;50:854-860.

3. Echániz-Aviles G,Velázquez-Meza E, CarnallaBarajas M, Soto-Noguerón A, Solórzano-Santos F, Miravete A, et al. Antimicrobial susceptibilities and capsular types of invasive Streptococcus pneumoniae isolated in children in Mexico City. Microbial Drug Resistance 1997;3:153-157 (SIREVA).

4. Kertesz DA, DiFabio JL, Brandileone M, Castañeda E, Echániz-Aviles G, Heitmann I, et al. Invasive Sreptococcus pneumoniae infection in Latin American children: results of the Pan American Health Organization surveillance study. Clin Infect Dis 1998;26:|355-|36|

5. Gómez-Barreto D, Calderón-Jaimes $E$, Rodríguez R, Espinosa-de los Monteros LE. Clinical outcome of invasive infections in children caused by highly penicillin-resistant Streptococcus pneumoniae compared with infections caused by penicillin-susceptible strains. Arch Med Res 2000;31:592-598.
6. DiFabio JL, Castañeda E, Agudelo C, De La Hoz F, Hortal M, Camou T, et al. Evolution of Streptococcus pneumoniae serotypes and penicillin susceptibility in Latin America, SirevaVigía Group, 1993 to 1999. Pediatr Infect Dis J 200I;20:959-967.

7. Gómez-Barreto D, Rodríguez RS, CalderónJaimes E, Espinosa LE. Bases Fisiopatológicas para la prevención de las infecciones por Streptococcus pneumoniae. Bol Med Hosp Infant Mex 200I;58:866-878.

8. Gómez-Barreto D, Calderón-Jaimes E, Rodriguez RS, Espinosa LE,Viña-Flores L, Jiménez-Rojas V. Carriage of antibiotic-resistant pneumococci in a cohort of a daycare center. Salud Publica Mex 2002 44:26-32.

9. Lopez C, Espinosa-Monteros LE, Jiménez V, Gomez D. Surveillance of antimicrobial resistance of Streptococcus pneumoniae isolates in children with pneumococcal infection from Mexico during 1997-2004. Presented at the 5th International Symposium on Pneumococci and Pneumococcal Diseases (ISPPD) 2006: 2006 April 2-6; Alice Springs Australia.

10. Lopez-Enriquez C, Blanco-Montero A, Espinosa-Monteros LE, Rodriguez R, De La Torre C, Gomez-Barreto D. Middle-Ear Fluid Streptococcus pneumoniae susceptibility and serotype and distribution in Mexican children with acute otitis media. Pediatrics 2008; I2I:SI 29. II. Solórzano-Santos F, Ortiz-Ocampo LA, Miranda-Novales MG, Echániz-Avilés G, SotoNoguerón A, Guiscafré-Gallardo H. Prevalence of Streptococcus pneumoniae serotypes on nasopharyngeal colonization in children of Mexico City. Salud Publica Mex 2005; 47:276-28I

12. Organización Panamericana de la Salud. Informe regional de SIREVA II: datos por país y por grupos de edad sobre las características de los aislamientos de streptococcus pneumoniae, Haemophilus influenzae y Neisseria meningitidis, en procesos invasivos 2000-2005 Washington, DC: OPS, 2007:234-242. Disponible en: http:// www.paho.org/Spanish/AD/THS/EV/LABS-Sireva. pdf

13. www.paho.org/spanish/AD/THS/EV/labs_ Sireva_ll_2006.pdf

I4. Espinosa-de los Monteros LE, Jiménez RV, Aguilar IF, Cashat-Cruz M, Reyes-López A, Rodríguez SR, et al. Serotype prevalence of Streptococcus pneumoniae isolates in healthy children attending day care centers of I 2 States of Mexico. Salud Publica Mex 2007:49:249-255.

15. Echaniz G. Serotype distribution and antimicrobial susceptibility of invasive pneumococcal isolates from Mexican children. Sireva Network 1996-2000. Presented at the 6th International Symposium on Pneumococci and Pneumococcal Diseases (ISPPD): 2008 June 8-12; Reykjavik, Iceland.

16. Gabastou J,Agudelo CL, De Cunto-

Brandileone MC, Castaneda E, Lemos APS, Di

Fabio JL, et al. Caracterización de aislamientos invasivos de S. pneumoniae, $H$. influenzae y $N$. 
meningitidis en América Latina y el Caribe: SIREVA II, 2000-2005. Rev Panam Salud Publica 2008:24:I-I5.

17. Kieninger DM, Kueper K, Steul K, Juergens $\mathrm{C}$, Ahlers $\mathrm{N}$ et al. Safety and immunogenic non-inferiority of $13 \mathrm{v}$ pneumococcal conjugate vaccine compared to 7 -valent pneumococcal conjugate vaccine given as a 4-dose series with routine vaccines in healthy infants and toddlers. Presented at the Interscience Conference of
Chemotherapy and Antibiotic Therapy (ICAAC) 2008; October 25-28, Washington DC.

18. Klinger CL, Snape MD, John T, Layton H,

Daniels $\mathrm{E}$ et al. Immunogenicity of a DTaP-

IPV-Hib and MenC vaccines in the UK when

administered with a I3-valent pneumococcal

conjugate vaccine. Presented at the Interscience

Conference of Chemotherapy and Antibiotic

Therapy (ICAAC) 2008,October 25-28,

Washington DC.
19. Grimprel E, Scott D, Laudat F, Baker S, Gruber W. Safety and Immunogenicity of a I3-valent pneumococcal conjugate vaccine given with routine pediatric vaccination to healthy infants in France. Presented at the Interscience Conference of Chemotherapy and Antibiotic Therapy (ICAAC) 2008,October 25-28,Washington DC 20. WHO. Pneumococcal conjugate vaccination for children.WHO Position Paper. Weekly Epidemiol Rec 2007; 82:93-104. 